Vol. 2 No. 1

September 2018

Hal : 22 - 26

\title{
Kajian:
}

Pembelajoran PPKn

\section{PERAN PEMERINTAH KECAMATAN DALAM UPAYA KESADARAN HUKUM TERHADAP KEPEMILIKAN KARTU TANDA PENDUDUK DI KECAMATAN BILAH HULU KABUPATEN LABUHAN BATU TAHUN 2015}

\author{
NURJANNAH \\ Program Studi Pendidikan Pancasila dan Kewarganegaraan \\ J1. SM. Raja No 126 - A KM. 3,5 Aek Tapa Rantauprapat 21901 \\ skynurjannah@gmail.com
}

\begin{abstract}
Abstrak
Pemerintah kecamatan mempunyai peran yang sangat penting dalam upaya meningkatkan kesadaran masyarakat terhadap kepemilikan Kartu Tanda Penduduk. Namun hal ini tidak terlepas pula bantuan dari aparat desa yang harus selalu berkoordinasi dengan pihak Kecamatan untuk menyampaikan kepada masyarakat bahwa KTP sangat penting di kehidupan mereka. Metode penelitian yang digunakan yaitu menggunakan pendekatan kualitatif dan menggunakan teknik pengumpulan data yaitu observasi, wawancara, dan studi dokumentasi. Waktu penelitian dilakukan bulan Mei sampai Juni 2017. Informan dalam penelitian camat, serta 11 kepala desa. Teknik analisa data menggunakan pengumpulan data, reduksi data, penyajian data, serta penarikan kesimpulan. Pemerintah Kecamatan Bilah Hulu Kabupaten Labuhan Batu sudah berupaya dan berperan dalam meningkatkan kesadaran hukum masyarakat terhadap kepemilikan KTP dengan diadakannya sosialisasi tentang pentingnya memiliki KTP melalui aparat - aparat desa, dan disosialisasikan kepada masyarakat dalam bentuk rapat dengan masyarakat, pertemuan organisasi dan pertemuan lainnya.
\end{abstract}

Kata kunci : peraturan daerah, pelayanan publik 
Vol. 2 No. 1

September 2018

Hal : 22 - 26

\section{Kajian:}

\section{Pembelajoran PPKn}

\section{PENDAHULUAN}

Penduduk adalah orang - orang yang berada di suatu wilayah yang terikat oleh aturan - aturan yang berlaku dan saling berinteraksi satu sama lain secara terus menerus. Indonesia merupakan negara yang memiliki penduduk dengan muatan aturan aturan dalam kehidupan bangsa Indonesia. KTP memiliki fungsi sebagai identitas diri, yang dapat menciptakan keakuratan data penduduk dan mendukung program pembangunan Indonesia. KTP sangat perlu untuk dapat menciptakan sistem administrasi kependudukan yang rapi dan teratur, mempermudah pemberian pelayanan publik oleh pemerintah kepada seluruh masyarakat. Berdasarkan hasil observasi data yang ditemukan jumlah penduduk di kecamatan Bilah Hulu Kabupaten Labuhan Batu Tahun 2015 ialah :Untuk membantu peangkat kecamatan atau desa dalam upaya meningkatkan kesadaran masyarakat untuk memiliki Kartu Tanda Penduduk khususnya KTP elektronik, peran yang harus dilakukan pemerintah kecamatan dan desa adalah meninjau ulang dengan melakukan sosialisasi langsung kepada masyarakat.

Dengan identitas tersebut akan mempermudah warga dalam mengurus segala kebutuhan yang bersangkutan dengan administrasi negara dan mendapatkan pengakuan dari negara. Selain itu sumber daya manusia dari pemerintahan yang mengurus juga harus menjalankan tugas pokok dan fungsi yang ingin melengkapi administrasi mereka yaitu Kartu Tanda Penduduk.

\section{Peraturan Daerah}

Peraturan daerah adalah peraturan perundang - undangan yang dibentuk oleh Dewan Perwakilan Rakyat Daerah (DPRD) dengan persetujuan bersama kepala daerah. Materi muatan peraturan daerah adalah seluruh materi muatan dalam rangka penyelenggaraan otonomi daerah dan tugas pembantuan, dan menampung kondisi khusus daerah serta penjabaran lebih lanjut peraturan perundang - undangan.

\section{Kesadaran Hukum Warga Negara}

Kesadaran adalah kesadaran akan perubahan. Sadar artinya merasa atau ingat (kepada keadaan yang sebenarnya), keadaan ingat akan dirinya, ingat kembali, siuman, bangun dan atau mengerti.

Menurut Kamus Besar Bahasa Indonesia (2002 : 975) “ Kesadaran merupakan kemampuan individu mengadakan hubungan dengan lingkungannya serta dengan dirinya sendiri dan mengadakan pembatasan terhadap lingkungannya serta terhadap dirinya sendiri melalui perhatian.

Kesadaran hukum pada hakekatnya bukanlah kesadaran akan hukum, tetapi terutama adalah kesadaran akan adanya atau terjadinya hukum. Kesadaran hukum baru dipersoalkan atau ramai dibicarakan ketika kesadaran hukum itu merosot atau tidak ada, atau terjadi pelanggaran hukum. Kesadaran hukum 
Vol. 2 No. 1

September 2018

Hal : 22 - 26

\section{Kajian:}

\section{Pembelajoran PPKn}

yang rendah cenderung pada pelanggaran hukum. ( Nogi, 2005: 304)

\section{Pelayanan Publik}

Dalam kamus besar bahasa Indonesia (1995), istilah pelayanan berasal dari kata " layan" yang artinya membantu menyiapkan atau mengurus segala apa yang diperlukan orang lain untuk perbuatan melayani.

Pelayanan publik adalah proses pemenuhan kebutuhan melalui aktivitas orang lain inilah yang dinamakan kegiatan yang bertujuan untuk membantu menyiapkan atau mengurus segala hal yang diperlukan orang lain. ( A.S Moenir A , 2002: 16)

\section{Kartu Tanda Penduduk(KTP)}

KTP adalah identitas resmi penduduk sebagai bukti diri yang diterbitkan oleh instansi pelaksana yang berlaku di seluruh wilayah Indonesia. Kartu ini wajib dimiliki bagi warga negara Indonesia dan warga negara asing yang memiliki izin tinggal tetap yang sudah berumur 17 tahun atau sudah pernah kawin atau telah kawin.

\section{Elektronik KTP ( E-KTP)}

Elektronik - KTP adalah kartu tanda penduduk yang dibuat secara elektronik dalam artian baik dari segi fisik maupun penggunaannya secara komputerisasi. Program E- KTP diluncurkan oleh kementrian dalam negeri pada bulan Februari 2011 dimana pelaksanaannya terbagi dalam tua tahap. Tahap pertama dimulai pada tahun 2011 dan berakhir pada 30 April 2012.

\section{Metodologi Penelitian}

Jenis penelitian menggunakan pendekatan kualitatif yaitu data dikumpulkan bukan berupa angka angka, melainkan data tersebut berasal dari naskah wawancara, catatan lapangan, dokumen pribadi, catatan memo, dan dokumen resmi lainnya. Sehingga menjadi tujuan penelitian ini adalah ingin menggambarkan realita empirik di balik fenomena secara mendalam, rinci dan tuntas. (Sugiyono, 2009 : 283)

\section{Lokasi Penelitian dan Waktu Penelitian}

Lokasi penelitian dilakukan di Kecamatan Bilah Hulu Kabupaten Labuhan Batu pada 11 Desa di Kecamatan Bilah Hulu. Waktu penelitian dilaksanakan pada bulan Mei hingga Juni 2017.

\section{Informan}

Yang menjadi narasumber dalam penelitian ini adalah orang - orang yang memiliki kemampuan dan paham mengenai masalah yang akan diteliti. Oleh karena itu, informan dalam penelitian ini adalah orang - orang yang terlibat dalam administrasi kependudukan seperti pihak kecamatan, serta kepala desa yang ada di Kecamatan Bilah Hulu.

\section{Instrumen Penelitian}


Vol. 2 No. 1

September 2018

Hal : 22 - 26

\section{Kajian:}

\section{Pembelajoran PPKn}

Instrumen yang digunakan untuk pengumpulan data dalam penelitian ini adalah wawancara, pedoman observasi.

\section{Teknik Pengumpulan Data}

Teknik pengumpulan data dalam penelitian ini adalah observasi, wawancara, serta studi dokumentasi.

\section{Teknik Analisis Data}

Analisis data adalah proses menggunakan dan mengurutkan data ke dalam pola, kategori, dan satuan uraian dasar sehingga dapat ditemukan tema dan dapat disarankan oleh data. Dari rumusan di atas dapatlah kita tarik garis besar bahwa analisis data bermaksud pertama - tama mengorganisasikan data. Data yang terkumpul banyak sekali dan terdiri dari catatan lapangan, komentar peneliti, gambar, foto, dokumen berupa laporan, biografi, artikel, dan sebagainya. (Sugiyono, 2009: 207)

\section{Hasil dan Pembahasan}

Masyarakat sudah banyak yang menyadari hukum yang berlaku terhadap kepemilikan KTP, namun masih banyak juga ditemukan masyarakat yang belum menyadari pentingnya KTP. Sehingga program yang dijalankan oleh pemerintahan belum berjalan dengan maksimal, mereka mulai memerlukan KTP pada waktu yang terdesak,sehingga masyarakat baru memahami KTP itu sangat penting disaat waktu yang terdesak tersebut, hal ini tidak sesuai dan tidak diharapkan oleh teori Nogi ( 2005: 304) dimana masyarakat memiliki kesadaran sejak awal dan timbul di dalam diri mereka, sebelum adanya desakan dari orang lain.

Masyarakat juga merasa terbuka dengan pergantian KTP menjadi EKTP sehingga tidak adanya penghalang bagi masyarakat untuk mengurus identitas mereka, dengan begitu tindakan yang dilakukan oleh Kepala Desa dengan Kecamatan sudah dijalankan dengan baik dan sesuai dengan teori A.S Moenir A(2002:16)

\section{PENUTUP}

peran pemerintah Kecamatan dalam upaya kesadaran hukum terhadap Kepemilikan Kartu Tanda Penduduk di Kecamatan Bilah Hulu Kabupaten Labuhanbatu Tahun 2015, maka dapat ditarik sebuah kesimpulan bahwa pemerintah di Kecamatan Bilah Hulu sudah berupaya dan berperan dalam meningkatkan kesadaran hukum masyarakat terhadap kepemilikan Kartu Tanda Penduduk dengan diadakannya sosialisasi tentang pentingnya memiliki Kartu Tanda Penduduk bagi masyarakat melalui aparat - aparat desa, dan disosialisasikan kepada masyarakat dalam bentuk rapat dengan masyarakat, pertemuan organisasi, dan pertemuan lainnya.

Dengan diadakannya sosialisasi tersebut Pemerintah Kecamatan Bilah Hulu 
Vol. 2 No. 1

September 2018

Hal : 22 - 26

\section{Kajian:}

\section{Pembelajaran PPKn}

berharap agar masyarakat memiliki kepedulian terhadap kepemilikan Kartu Tanda Penduduk. Berdasarkan hasil observasi data yang ditemukan jumlah penduduk di Kecamatan Bilah Hulu Kabupaten Labuhanbatu Tahun 2015 yaitu 30.296 penduduk yang sudah melakukan perekaman dan 8.919 penduduk yang belum memiliki KTP.

\section{DAFTAR PUSTAKA}

Harditono R. Siti. 2012. Psikologi Perkembangan. Yogyakarta
: Gajah Mada University Press

Undang - undang no 25 Tahun 2009 tentang Kebijakan Publik

Undang - undang no 23 Tahun 2006 tentang Administrasi kependudukan

Peraturan Presiden Nomor 26 Tahun 2009 tentang Penerapan KTP berbasis Nomor Induk Kependudukan 